\title{
Reactivity of some structural analogs of dehydroacetic acid with o-phenylenediamine
}

\author{
Nabila Aït-Baziz, ${ }^{\text {a,b* }}$ Yahia Rachedi, ${ }^{b}$ and Artur M. S. Silva ${ }^{c}$ \\ ${ }^{a}$ Scientific and Technical Research Center in Physical and Chemical Analyses (C.R.A.P.C), BP \\ 248 RP, 16004 Algiers, Algeria \\ ${ }^{b}$ Laboratory of Applied Organic Chemistry, Faculty of Chemistry, USTHB, BP 32, El-Alia, \\ Algiers, Algeria \\ ${ }^{c}$ Departments of Chemistry, University of Aveiro, 3810-193, Aveiro, Portugal \\ E-mail: aitbaziznabila@yahoo.fr
}

\begin{abstract}
4-Hydroxy-6-methyl-3-(3-arylpropanoyl)-2H-pyran-2-ones 14a-c and 4-hydroxy-6-methyl-3-(5phenylpentanoyl)-2H-pyran-2-one 15, which are structural analogs of dehydroacetic acid (DHA) 1, react with $o$-phenylenediamine 2 according to the solvents and reaction conditions. New heterocyclic compounds have been obtained and characterized.
\end{abstract}

Keywords: DHA analogs, pyrone, triacetic acid lactone, o-phenylenediamine, benzimidazole, MW irradiation

\section{Introduction}

3-Acetyl-4-hydroxy-6-methyl-2H-pyran-2-one (dehydroacetic acid: DHA) 1 displays a rich and varied chemistry. It can be readily converted into the other heterocyclic systems, e.g., pyrazoles, ${ }^{1,2}$ benzothiazepines, ${ }^{3}$ benzodiazepines, ${ }^{4-6}$ and pyrimidines, ${ }^{7}$ through its condensation with a variety of bis-nucleophiles. The literature ${ }^{4,5}$ indicates that refluxing DHA 1 with $o$ phenylenediamine (o-PDA) 2 in ethanol gives the drivative 3-[(1E)- $N$-(2-aminophenyl) ethanimidoyl]-4-hydroxy-6-methyl-2H-pyran-2-one 3, which can used as first stage in the formation of 3,4-dihydro-1,5-benzodiazipines 4 by the addition of aromatic aldehydes in the presence of trifluoroacetic acid as catalyst. ${ }^{4}$ However, El Abassi and coworkers ${ }^{6}$ indicated that the reaction of DHA 1 with o-PDA 2 in different alcohols leads to 2-alkoxycarbonylmethyl 4methyl-1,5-benzodiazepines 5, 4-acetyl methylene 1,5-benzodiazepin-2-one 6, benzimidazole 7 and benzimidazolone 8 and 4-hydroxy-6-methyl-2-pyrone (triacetic acid lactone: TAL) 9 which is not isolated (Scheme 1). The TAL 9 is a natural product of polyketide origin ${ }^{8}$ but it can also be obtained by deacetylation of DHA 1 in sulfuric acid. ${ }^{9}$ 


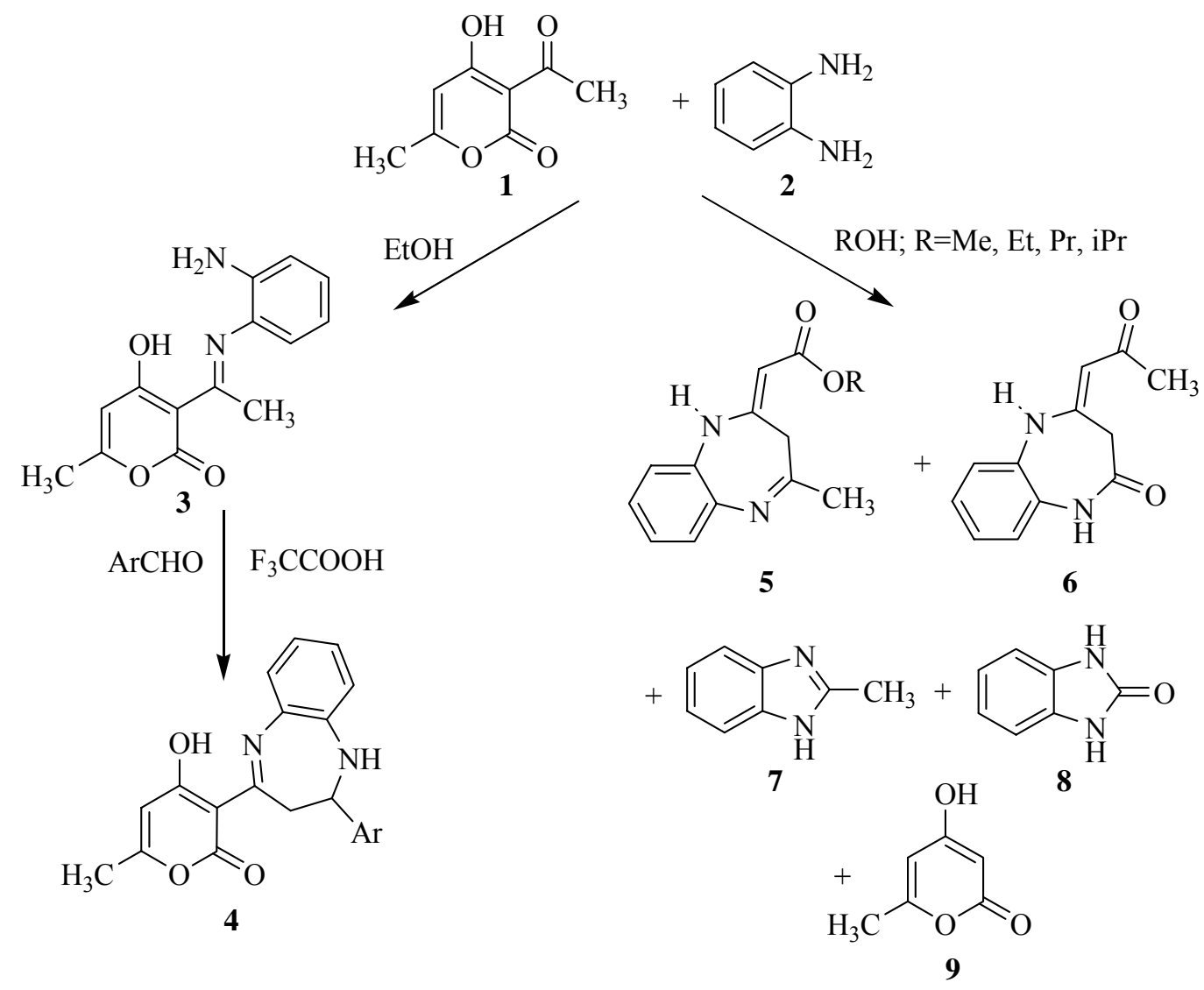

\section{Scheme 1}

In this work, we were interested in exploring some chemistry of the structural analogs 4hydroxy-6-methyl-3-(3-arylpropanoyl)-2H-pyran-2-ones 14a-c and 4-hydroxy-6-methyl-3-(5phenylpentanoyl)-2H-pyran-2-one 15 of DHA 1 with o-PDA 2 (Scheme 2). It appeared to us that this study is interesting because it lets suppose the formation of the analogs of the compound $\mathbf{3}$, which can give access to the formation of the 2-alkylbenzimidazole with the separation of TAL 9 or to the formation of the benzodiazepines by an intramolecular attack of the free $-\mathrm{NH}_{2}$ group at position 2 or position 4 of the pyrone ring. 


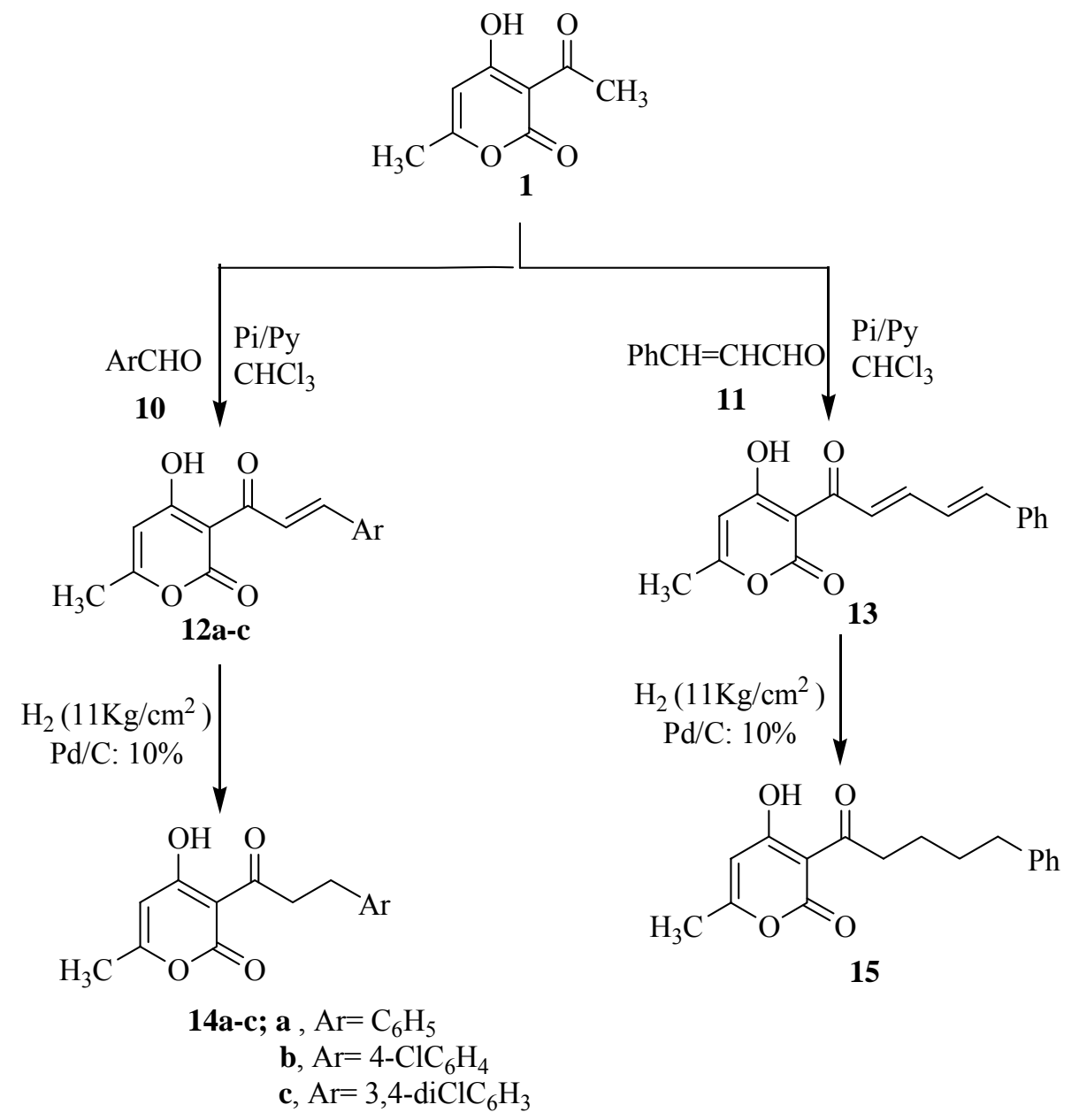

Scheme 2

\section{Results and Discussion}

4-Hydroxy-6-methyl-3-(3-arylpropanoyl)-2H-pyran-2-ones 14a-c and 4-hydroxy-6-methyl-3-(5phenylpentanoyl)-2H-pyran-2-one 15 were obtained via a selective hydrogenation reaction of 4hydroxy-6-methyl-3-[(2E)-3-arylprop-2-enoyl]-2H-pyran-2-ones 12a-c and 4-hydroxy-6-methyl3-[(2E,4E)-5-phenylpenta-2,4-dienoyl]-2H-pyran-2-one 13. This method uses palladium on carbon $(\mathrm{Pd} / \mathrm{C}: 10 \%)$ as catalyst under a pressure of $11 \mathrm{Kg} / \mathrm{cm}^{2}$ of hydrogen in ethyl acetate ${ }^{10}$ (Scheme 2).

The compounds 12a-c and 13 were obtaineded by Knœvenagel condensation of DHA 1 with the corresponding aldehydes 10a-c and 11, using pyridine and piperidine as catalysts under thermal refluxing or under microwave MW irradiation in chloroform as solvent. ${ }^{2,10,11}$ As far as we are aware, the spectroscopic analysis of compounds 14c and 15 have not been reported in the literature. We give in this work their detailed spectroscopic data. 
The electron impact mass spectra (EI MS) showed the addition of one molecule of hydrogen to the compound 12c and two molecules of hydrogen to the compound 13. The ${ }^{1} \mathrm{H}$ NMR spectra showed the existence of two methylenes $-\mathrm{CH}_{2}$ - in the structure of $14 \mathrm{c}$ and four methylenes $\mathrm{CH}_{2}$ - in the structure of 15. The ${ }^{1} \mathrm{H}$ NMR spectra of the compounds $\mathbf{1 4} \mathrm{c}$ and $\mathbf{1 5}$ also presented the signals at $16.56 \mathrm{ppm}$ and at $16.10 \mathrm{ppm}$, respectively. These signals assigned to proton $\mathrm{H}-\mathrm{O}$ at the site 4 of the pyrone ring. The position of $\mathrm{H}-\mathrm{O}$ in the structures of 12c and 13 has been confirmed by HMBC spectrum which showed their connectivities with C-3, C-4 and C-5 of the pyrone ring (Figure 1).

The study of the reactivity of the compounds 13a-c and 14 with o-PDA 2 was achieved in ethanol and in toluene as solvents under several reaction conditions.

We reacted compounds 14a-c and 15 with o-PDA 2 in ethanol at room temperature for 6 hours (procedure A), under thermal refluxing for 30 minutes (procedure B) and under MW irradiation at $100{ }^{\circ} \mathrm{C}$ during 1 minutes (procedure $\mathrm{C}$ ) and 4 minutes (procedure $\mathrm{D}$ ).

For the first three procedures (A, B and C), the same products 16a-c and 17 were separated for the four chosen cases. The best yields were obtained at room temperature (procedure A) (Scheme 3).
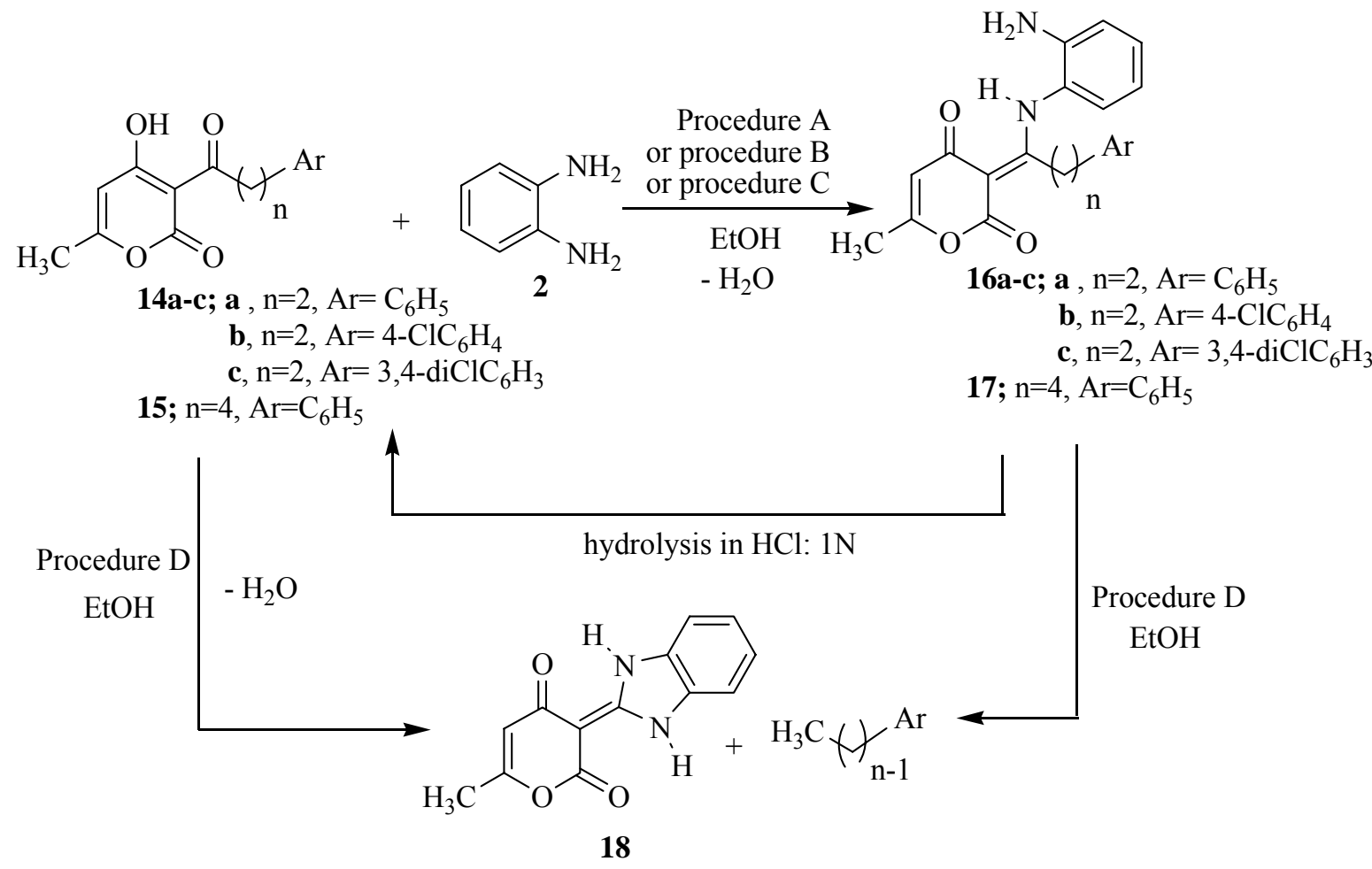

Scheme 3. Procedure A: at rt for $6 \mathrm{~h}$; Procedure B: thermal refluxing for $1 \mathrm{~h}$; Procedure C: MW irradiation at $100 \mathrm{~W}$ for $1 \mathrm{~min}$; Procedure D: MW irradiation at $100 \mathrm{~W}$ for $4 \mathrm{~min}$. 
For the procedure using MW irradiation for 4 minutes (procedure D) the behaviour of 14a-c and 15 with $o$ - PDA 2 was very different. The four compounds give the same product 18 (Scheme 3) with departure of one molecule of water and a molecule of alkylbenzene. We notes that the temperature of the mixture at the end of the reaction for the procedure $\mathrm{C}$ was $77-78{ }^{\circ} \mathrm{C}$, whereas the temperature of the mixture at the end of the reaction for the procedure $\mathrm{D}$ was $89-92$ ${ }^{\circ} \mathrm{C}$.

We have prolonged the agitation at room temperature for one week and the refluxing thermal for 24 hours, but we did not succeed in obtaining the compound 18; it was always the derivatives 16a-c and 17 which were formed.

Compound 18 was also obtained from 16a-c and 17 in ethanol, under MW irradiation at 100 $\mathrm{W}$ for $4 \mathrm{~min}$.

The EI MS of 16a-c and 17 confirmed the condensation of only one molecule of $o$-PDA with loss of one molecule of water during the reaction. The ${ }^{1} \mathrm{H}$ NMR spectra showed a signal at 3.70$3.82 \mathrm{ppm}$ attributed to two equivalent protons where HSQC experiment confirmed that these two protons are carried by an heteroatom, which can be only a nitrogen atom. ${ }^{1} \mathrm{H}$ NMR spectra showed the signals at $5.72 \mathrm{ppm}$ and at $2.22 \mathrm{ppm}$, assigned to the protons $\mathrm{H}-\mathrm{C} 5$ of the pyrone ring and $\mathrm{H}-\mathrm{C} 7$ of the methyl, respectively. The ${ }^{1} \mathrm{H}$ NMR spectra also showed a signal at $15.30 \mathrm{ppm}$. Originally, we considered a structure analogous to the compound 3, but the HMBC experiment showed some connectivities between this signal at $15.30 \mathrm{ppm}$ and the three signals of the carbons C-3, C-3' and the C-4', which confirmed that this proton is not carried by the oxygen atom at the site 4 , but it is carried by the nitrogen atom at the site 3' (Figure 1), where the derivatives 15a-c and 16 were obtained.

The hydrolysis reaction of 15a-c and $\mathbf{1 6}$ in $\mathrm{HCl}$ : $1 \mathrm{~N}$ under thermal refluxing for 1 hour or under MW irradiation at $100 \mathrm{~W}$ for 3 minutes permitted the recuperation of 13a-c and 14 with $O$ PDA 2 (Scheme 3).

The EI MS of the compound 18 showed the condensation of only one molecule of o- PDA 2 with loss of one molecule of water and a molecule of alkylbenzene by the observation of the molecular peak at 242(80\%), where the molecular formula $\mathrm{C}_{13} \mathrm{H}_{10} \mathrm{~N}_{2} \mathrm{O}_{3}$ was confirmed.

The ${ }^{1} \mathrm{H}$ NMR spectra confirmed the structure of the compound $\mathbf{1 8}$ by the observation of two signals at $2.15 \mathrm{ppm}$ and at $5.83 \mathrm{ppm}$ assigned to the protons $\mathrm{H}-\mathrm{C} 7$ of the methyl and $\mathrm{H}-\mathrm{C} 5$ of the pyrone ring, respectively. The ${ }^{1} \mathrm{H}$ NMR spectra showed also two doublets of doublets in the domain of the aromatic protons at $7.32 \mathrm{ppm}$ and at $7.75 \mathrm{ppm}$, each one of them assigned to two protons of the aromatic ring in symmetry, which is in perfect accord with the ${ }^{13} \mathrm{C}$ NMR spectra data, where the presence of two intense signals, each one of them represented two carbons (C5', C8') and (C6', C7') of the aromatic ring in symmetry. These data were confirmed by HSQC experiment. The ${ }^{1} \mathrm{H}$ NMR spectra showed a signal centered on $13.15 \mathrm{ppm}$ represented the sum of two protons, which is assigned to the two protons $\mathrm{H}-\mathrm{N}$ in symmetry. The position of these protons was confirmed by an HMBC experiment (Figure 1). 

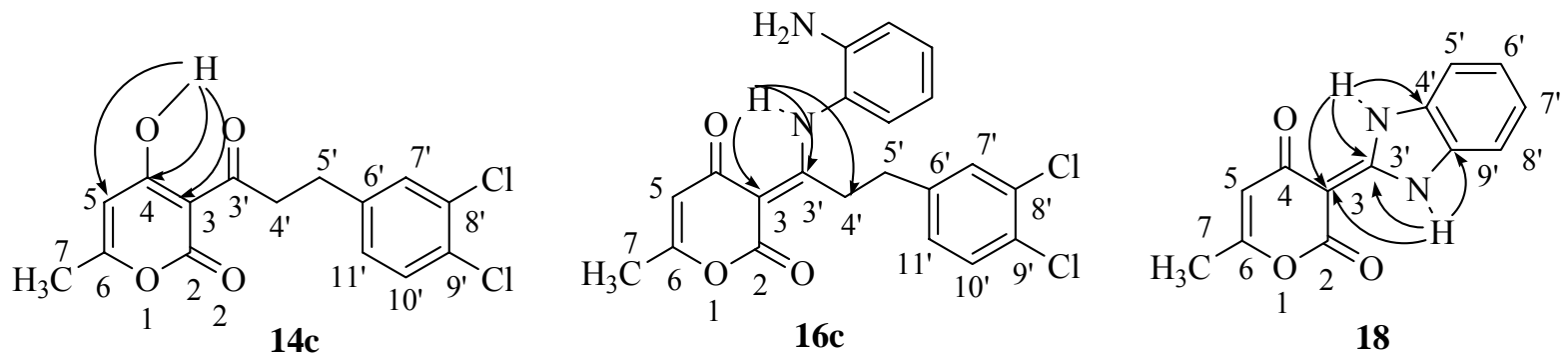

Figure 1. Important connectivities found in the HMBC spectra of compounds 14c, 16c and 18.

In toluene, under thermal refluxing for 3 hours or under MW irradiation at $200 \mathrm{~W}$ for 4 minutes, we could separate two products from every compound 13a-c and 14 with o-PDA 2 . The first product is the same for the four reactions. It was separated by filtration at ebullition (111 $\left.{ }^{\circ} \mathrm{C}\right)$. Its spectroscopic data revealed that it was the TAL 9.

After the cooling of every filtrate and filtration, the second products 19a-c or 20 were separated (Scheme 4).

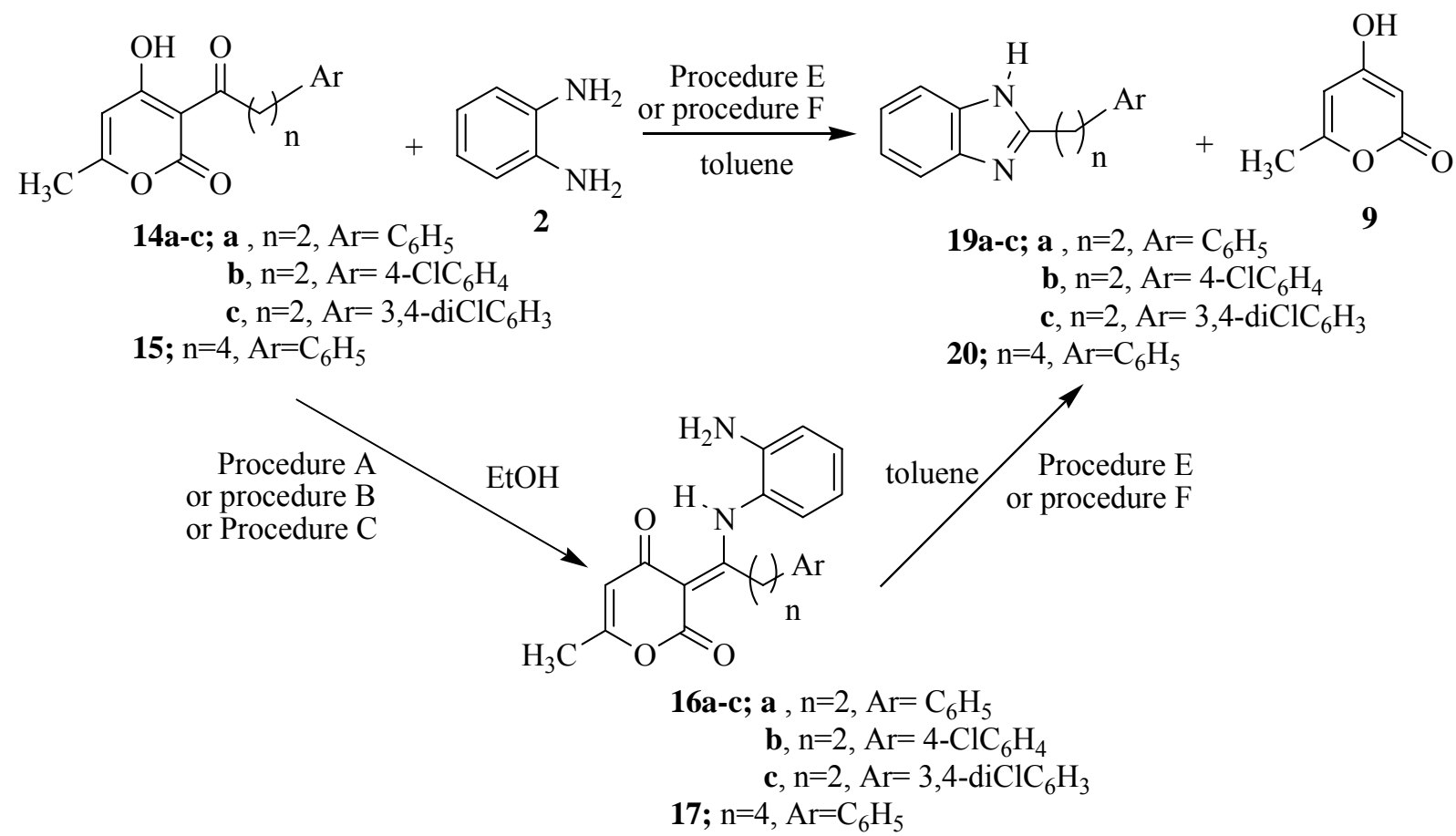

Scheme 4. Procedure A: at $\mathrm{rt}$ for $6 \mathrm{~h}$; Procedure B: thermal refluxing for $1 \mathrm{~h}$; Procedure C: MW irradiation at $100 \mathrm{~W}$ for $1 \mathrm{~min}$; Procedure D: MW irradiation at $100 \mathrm{~W}$ for $4 \mathrm{~min}$; Procedure E: thermal refluxing for $3 \mathrm{~h}$; Procedure F: MW irradiation at $200 \mathrm{~W}$ for $4 \mathrm{~min}$. 
The formation of the derivatives 2-alkylbenzimidazoles 18a-c and 19 was confirmed initially by EI MS where the fixing of only one molecule of o-PDA 2 with the departure of TAL 9 molecule. These compounds were also confirmed by ${ }^{1} \mathrm{H}$ and ${ }^{13} \mathrm{C}$ NMR spectra. The derivatives 18a-c and 19 with TAL 9 were also obtained from 16a-c and 17 under the same reaction conditions ( Procedures E or F).

Table 1. Procedures and physical data of the products 16a-c, 17, 18, 19a-c, 20 and 9

\begin{tabular}{|c|c|c|c|}
\hline Product & Procedure & Yield (\%) & $\operatorname{Mp}\left({ }^{\circ} \mathrm{C}\right)$ \\
\hline \multirow{3}{*}{$16 a$} & A & 72 & \multirow{3}{*}{220} \\
\hline & $\mathrm{B}$ & 65 & \\
\hline & $\mathrm{C}$ & 70 & \\
\hline \multirow{3}{*}{$16 b$} & A & 86 & \multirow{3}{*}{164} \\
\hline & $\mathrm{B}$ & 81 & \\
\hline & $\mathrm{C}$ & 82 & \\
\hline \multirow{3}{*}{$16 c$} & A & 93 & \multirow{3}{*}{179} \\
\hline & $\mathrm{B}$ & 82 & \\
\hline & $\mathrm{C}$ & 89 & \\
\hline \multirow{3}{*}{17} & A & 96 & \multirow{3}{*}{165} \\
\hline & B & 90 & \\
\hline & $\mathrm{C}$ & 92 & \\
\hline \multirow{4}{*}{18} & \multirow{4}{*}{$\mathrm{D}$} & 87 (from 14a) & \multirow{4}{*}{45} \\
\hline & & 81 (from 14b) & \\
\hline & & 90 (from $14 c)$ & \\
\hline & & 93 (from15) & \\
\hline \multirow{2}{*}{$19 a$} & $\mathrm{E}$ & 75 & \multirow{2}{*}{132} \\
\hline & $\mathrm{F}$ & 84 & \\
\hline \multirow{2}{*}{$19 b$} & $\mathrm{E}$ & 78 & \multirow{2}{*}{165} \\
\hline & $\mathrm{F}$ & 86 & \\
\hline \multirow{2}{*}{$19 c$} & $\mathrm{E}$ & 79 & \multirow{2}{*}{160} \\
\hline & $\mathrm{F}$ & 84 & \\
\hline \multirow{2}{*}{20} & $\mathrm{E}$ & 71 & \multirow{2}{*}{130} \\
\hline & $\mathrm{F}$ & 92 & \\
\hline \multirow{6}{*}{9} & $\mathrm{E}$ & $72($ from $14 a)$ & \multirow{6}{*}{187} \\
\hline & $\mathrm{F}$ & 78 (from $14 a)$ & \\
\hline & $\mathrm{E}$ & $70($ from $14 b)$ & \\
\hline & $\mathrm{F}$ & 81 (from14b) & \\
\hline & $\mathrm{E}$ & 75 (from $14 c)$ & \\
\hline & $\mathrm{F}$ & $80($ from $14 c)$ & \\
\hline
\end{tabular}


Table 1. Continued

\begin{tabular}{cccc}
\hline Product & Procedure & Yield $(\%)$ & $\mathrm{Mp}\left({ }^{\circ} \mathrm{C}\right)$ \\
\hline $\mathrm{E}$ & 79 (from15) & \\
$\mathrm{F}$ & 87 (from 15) & \\
\hline
\end{tabular}

Procedure A: reaction mixture steered at $\mathrm{rt}$ for $6 \mathrm{~h}$, solvent: ethanol.

Procedure B: reaction mixture submitted to the thermal reflux for $1 \mathrm{~h}$, solvent: ethanol.

Procedure C: reaction mixture submitted to the MW irradiation for $1 \mathrm{~min}$, solvent: ethanol.

Procedure D: reaction mixture submitted to the MW irradiation at $100 \mathrm{~W}$ for $4 \mathrm{~min}$, solvent: ethanol.

Procedure E: reaction mixture submitted to the thermal reflux for $3 \mathrm{~h}$, solvent: toluene.

Procedure F: reaction mixture submitted to the MW irradiation at $200 \mathrm{~W}$ for $4 \mathrm{~min}$, solvent: toluene.

\section{Conclusions}

The study of the reactivity of the compounds 14a-c and 15, analogs of the DHA 1, with $o$-PDA 2 permitted the synthesis some new heterocyclic compounds. The compounds 14a-c and 15 with $o-$ PDA 2 react according to the reaction conditions. In ethanol, under thermal refluxing, under agitation at room temperature or under MW irradiation at $100 \mathrm{~W}$ for 1 minute we obtained 16a-c and 17. However, under MW irradiation at $100 \mathrm{~W}$ for 4 minutes, we obtained the product 18. In toluene, under thermal refluxing or under MW irradiation at $200 \mathrm{~W}$, we have achieved an important reaction of deacylation, where we have separated the TAL 9 and 2arylalkylbenzimidazoles compounds 19a-c and 20 with good yields.

\section{Experimental Section}

General. The catalytic reductions of 12a-c and $\mathbf{1 3}$ were carried out in a quick closure autoclave (Prolabo). The reactions were carried out in a microwave oven dedicated to organic synthesis (Milestone, Lab Terminal 800 controller) at $\mathrm{P}=1$ bar.

Melting points were determined on a Stuart scientific SPM3 apparatus fitted with a microscope and are uncorrected. ${ }^{1} \mathrm{H}$ and ${ }^{13} \mathrm{C}$ NMR spectra were recorded on a Bruker DRX 300 spectrometer, operating at 300.13 and $75.47 \mathrm{MHz}$, respectively; the chemical shifts are expressed in $\delta(\mathrm{ppm})$ and coupling constants $(\mathrm{J})$ in $(\mathrm{Hz}) .{ }^{1} \mathrm{H}$ and ${ }^{13} \mathrm{C}$ NMR assignments were made using HSQC and HMBC experiments. Electron impact mass spectra (EI MS) were obtained at $70 \mathrm{eV}$ electron impact ionisation using Nermag R 10-10C Quadruple mass spectrometer. Infrared spectra were recorded on Magna-IR 550 series II Nicolet apparatus, using potassium bromide pellets. UV spectra were recorded on Cary 50 Scan UV-Visible spectrometer in acetonitrile and elemental analyses $\mathrm{CHN}$ performed with a Perkin-Elmer 2400 series II CHNO/S at the Scientific 
and Technical Research Center in Physical and Chemical Analyses (C.R.A.P.C), Algiers, Algeria.

The compounds 12a-c and 13 were prepared by following the literature. ${ }^{11}$ The compounds 14a-b were obtained according to the method described in literature, ${ }^{10}$ which is the same synthesis method used for 14c and 15. The yields of all compounds are reported in Table 1.

General method for preparation 3-[3-(3,4-dichlorophenyl)propanoyl]-4-hydroxy-6-methyl2H-pyran-2-one (14c) and 4-hydroxy-6-methyl-3-(5-phenylpentanoyl)-2-H-pyran-2-one (15) A mixture of 12c $(6.52,20 \mathrm{mmol})$ or $13(5.64,20 \mathrm{mmol})$ with $10 \%$ of its weight of $\mathrm{Pd} / \mathrm{C}: 10 \%$ in ethyl acetate $(50 \mathrm{ml})$ was introduced in autoclave under pressure $11 \mathrm{Kg} / \mathrm{cm}^{2}$ of hydrogen $\mathrm{H}_{2}$ for $24 \mathrm{~h}$ at rt. After filtration and evaporation of solvent, the resultant was crystallized from ethanol.

3-[3-(3,4-Dichlorophenyl)propanoyl]-4-hydroxy-6-methyl-2H-pyran-2-one (14c). Yield (6.10 g, 93\%) as Pale yellow powder; mp $118{ }^{\circ} \mathrm{C} ;{ }^{1} \mathrm{H}$ NMR $\left(\mathrm{CDCl}_{3}\right) \delta 2.26(\mathrm{~s}, 3 \mathrm{H}, 7-\mathrm{CH} 3), 3.01(\mathrm{t}, \mathrm{J}$ $6.12 \mathrm{~Hz}, 2 \mathrm{H}, \mathrm{H}-\mathrm{C} 4$ '), 3.32(t, J 6.12 Hz, 2H, H-C5'), 5.91 (s, 1H, H-5), 7.12-7.20 (m, 3H, Ar), $16.18(\mathrm{~s}, 1 \mathrm{H}, \mathrm{OH}) ;{ }^{13} \mathrm{C}$ NMR $\left(\mathrm{CDCl}_{3}\right) \delta 20.69(\mathrm{C}-7), 29.30$ (C-5'), 43.13 (C-4'), 99.49 (C-3), 101.50 (C-5), 132.18(C-8'), 129.74(C-10'), 132.43( C-9'), 130,67(C-7'), 135.40(C-11'), 140.54 (C-6’), 160.98 (C-2), 168.85 (C-6), 181.19 (C-4), 207.70 (C-3'); EI MS m/z \% 326 (27, M ${ }^{+}$); IR $\left(v, \mathrm{~cm}^{-1}\right) 3450,1735,1720,1632,1618 ; \mathrm{UV}\left(\lambda_{\max }\left(\varepsilon 10^{-1}\right) \mathrm{nm}\right) 228(860), 260$ (700); Anal. Calcd. for $\mathrm{C}_{15} \mathrm{H}_{12} \mathrm{Cl}_{2} \mathrm{O}_{4}$ : C, 55.07; H, 3.70. Found: C, 55.10; H, 3.62.

4-Hydroxy-6-methyl-3-(5-phenylpentanoyl)-2H-pyran-2-one (15). Yield (5.50 g, 96\%) as Pale yellow microcrystals; mp $96{ }^{\circ} \mathrm{C} ;{ }^{1} \mathrm{H}$ NMR $\left(\mathrm{CDCl}_{3}\right) \delta 1.73(\mathrm{~m}, J 6.20 \mathrm{~Hz}, J 7.34 \mathrm{~Hz}, J 7.47$ Hz, 4H, H-C5',H-C6'), 2.27 (s, 3H,7-CH3), 3.11(t, J 6.20 Hz, 2H, H-C4'), 3.12(t, J 7.34 Hz, $2 \mathrm{H}, \mathrm{H}-\mathrm{C} 7$ ') 5.94 (s, 1H, H-5), 7.19-7.31(m, 5H, Ar), $16.10(\mathrm{~s}, 1 \mathrm{H}, \mathrm{OH}) ;{ }^{13} \mathrm{C} \mathrm{NMR}\left(\mathrm{CDCl}_{3}\right) \delta$ 20.64(C-7), 23.60 (C-5'), 30.88 (C-6'), 35.75 (C-7'), 41.43 (C-4'), 99.50 (C-3), 101.52 (C-5), 125.70 (C-11'), 128.28 (C-10', C-12'), 128,41 (C-9', C-13'), 142.26 (C-8'), 160.96 (C-2), 168.87 (C-6), 181.25 (C-4), 207.68 (C-3'); EI MS m/z \% $286\left(10, \mathrm{M}^{+}\right)$; IR ( v, cm $\left.{ }^{-1}\right)$ 3482, 1736, 1722, 1638, 1616 ; UV ( $\left.\lambda_{\max }\left(\varepsilon 10^{-1}\right) \mathrm{nm}\right) 230$ (940),280 (760); Anal. Calcd. for $\mathrm{C}_{17} \mathrm{H}_{18} \mathrm{O}_{4}$ : C, 71.31; H, 6.34. Found: C, 71.28; H, 6.39.

General method for preparation (3E)-3-\{1-[(2-aminophenyl)amino]-3-arylpropylidene\}-6methyl-2H-pyran-2,4(3H)-diones (16a-c) and (3E)-3-\{1-[(2-aminophenyl)amino]-5phenylpentylidene\}-6-methyl-2H-pyran-2,4(3H)-dione (17)

A solution of 14a-c or 15 (1 mmol) with o-PDA $(0.108 \mathrm{~g}, 1 \mathrm{mmol})$ in ethanol $(10 \mathrm{ml})$ was steered at $\mathrm{rt}$ for $6 \mathrm{~h}$ or refluxed under thermal heating for $30 \mathrm{~min}$ or under MW irradiation at 100 $\mathrm{W}$ for $1 \mathrm{~min}$. After cooling and filtration, the resultants were crystallized from ethanol to afforded the corresponding compounds 16a-c or 17.

(3E)-3-\{1-[(2-Aminophenyl)amino]-3-phenylpropylidene\}-6-methyl-2H-pyran-2,4(3H)dione (16a). Beige powder; M.p. $220{ }^{\circ} \mathrm{C} ;{ }^{1} \mathrm{H} \mathrm{NMR}(\mathrm{CDCl} 3) \delta$ 2.22(s, 3H,7-CH3), 3.21(t, $J 6.98$ Hz, 2H, H-C4'), 2.85(t, J 6.98 Hz, 2H, H-C5'),3.70(s, 2H, NH$), 5.79$ (s, 1H, H-C5), 6.787.26(m, 9H, Ar, Ar'-N), 15.29 (s, 1H, NH); ${ }^{13} \mathrm{C}$ NMR(CDCl3) $\delta$ 19.93(C-7), 33.62(C-4'), 33.86 
(C-5'), 96.69 (C-3), 107.21 (C-5), 116.32 (C-5"), 118.55 (C-8"), 121.80 (C-4"), 126.26 (C-11"), 127.31(C-6"), 128.42 (C-9', C-13'), 128.50 (C-10', C-12'), 129.68(C-7"), 140.39(C-9"), 162.67(C-6), 163.64(C-4), 180.60 (C-3'), 185.79 (C-2) ; EI MS m/z (\%) 348(59, M+') ; IR ( v, $\left.\mathrm{cm}^{-1}\right)$ 3022, 1684(C=O), 1600, 1332; UV $\left(\lambda_{\max }\left(\varepsilon 10^{-1}\right) \mathrm{nm}\right) 228(818), 315(620)$. Anal. Calcd. for $\mathrm{C}_{21} \mathrm{H}_{20} \mathrm{~N}_{2} \mathrm{O}_{3}: \mathrm{C}, 72.40 ; \mathrm{H}, 5.79 ; \mathrm{N}, 8.04$. Found: $\mathrm{C}, 72.32 ; \mathrm{H}, 5.83 ; \mathrm{N}, 8.11$.

(3E)-3-\{1-[(2-Aminophenyl)amino]-3-(4-chlorophenyl)propylidene\}-6-methyl-2H-pyran2,4(3H)-dione (16b). Beige powder; M.p. $164{ }^{\circ} \mathrm{C}$; ${ }^{1} \mathrm{H} \mathrm{NMR}(\mathrm{CDCl} 3) \delta 2.19$ (s, 3H,7-CH3), $\left.3.15(\mathrm{t}, J 6.97 \mathrm{~Hz}, 2 \mathrm{H}, \mathrm{H}-\mathrm{C} 4 \text { '), 2.81(t, J } 6.97 \mathrm{~Hz}, 2 \mathrm{H}, \mathrm{H}-\mathrm{C} 5 \text { '), 3.75(s, 2H, NH})_{2}\right), 5.79$ (s, 1H, HC5), 6.78-7.26(m, 8H, Ar, Ar'-N), $15.28(\mathrm{~s}, 1 \mathrm{H}, \mathrm{NH}) ;{ }^{13} \mathrm{C} \mathrm{NMR}(\mathrm{CDCl} 3) \delta 19.93(\mathrm{C}-7), 32.90(\mathrm{C}-$ 4'), 33.78 (C-5'), 96.67 (C-3), 107.21 (C-5), 116.36 (C-5"), 118.55 (C-8"), 121.67 (C-4"), 132.03 (C-11"), 127.22(C-6"), 129.78 (C-9', C-13'), 128.50 (C-10', C-12'), 129.82(C-7"),138.84(C-9"),

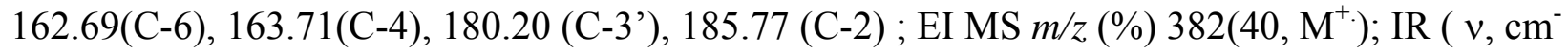
$\left.{ }^{1}\right) 3051,1685(\mathrm{C}=\mathrm{O}), 1600,1333$; UV $\left(\lambda_{\max }\left(\varepsilon 10^{-1}\right) \mathrm{nm}\right) 228(896), 316(698)$. Anal. Calcd. for $\mathrm{C}_{21} \mathrm{H}_{19} \mathrm{ClN}_{2} \mathrm{O}_{3}$ : C, 65.88; H, 5.00;N, 7.32. Found: C, 65.83; H, 5.09; N, 7.29.

(3E)-3-\{1-[(2-Aminophenyl)amino]-3-(3,4-dichlorophenyl)propylidene\}-6-methyl-2Hpyran-2,4(3H)-dione (16c). Beige powder; m.p. $179{ }^{\circ} \mathrm{C} ;{ }^{1} \mathrm{H} \operatorname{NMR}\left(\mathrm{CDCl}_{3}\right) \delta 2.19$ (s, 3H,7CH3), 3.15(t, J $6.98 \mathrm{~Hz}, 2 \mathrm{H}, \mathrm{H}-\mathrm{C} 4$ '), 2.78(t, J $6.98 \mathrm{~Hz}, 2 \mathrm{H}, \mathrm{H}-\mathrm{C} 5$ '),3.84(s, 2H, $\left.\mathrm{NH}_{2}\right), 5.78$ (s, 1H, H-C5), 6.78-7.26(m, 7H, Ar, Ar'-N), 15.28 (s, 1H, NH); ${ }^{13} \mathrm{C}$ NMR(CDCl3) $\delta 19.91(\mathrm{C}-7)$, 32.54(C-4'), 33.49 (C-5'), 96.62 (C-3), 107.18 (C-5), 116.44 (C-5"), 118.54 (C-8"), 121.48 (C4"), 132.18 (C-11"), 127.12(C-6"), 130.36(C-9'), 130.26(C-13'), 130.23(C-10'), 127.91(C-12'), 129.89(C-7"),140.57(C-9"), 162.69(C-6), 163.76(C-4), 179.82 (C-3'), 185.71(C-2) ; EI MS m/z (\%) 416(40, $\left.\mathrm{M}^{+}\right)$; IR $\left(v, \mathrm{~cm}^{-1}\right) 3053,1684(\mathrm{C}=\mathrm{O}), 1601,1332$; UV $\left(\lambda_{\max }\left(\varepsilon 10^{-1}\right) \mathrm{nm}\right) 229(983)$, 317(709). Anal. Calcd. for $\mathrm{C}_{21} \mathrm{H}_{18} \mathrm{Cl}_{2} \mathrm{~N}_{2} \mathrm{O}_{3}: \mathrm{C}, 60.44 ; \mathrm{H}, 4.35 ; \mathrm{N}, 6.71$. Found: $\mathrm{C}, 60.49 ; \mathrm{H}, 4.31$; $\mathrm{N}, 6.73$.

(3E)-3-\{1-[(2-Aminophenyl)amino]-3-phenylpentylidene\}-6-methyl-2H-pyran-2,4(3H)dione (17). Pale-brown powder; mp. $165{ }^{\circ} \mathrm{C} ;{ }^{1} \mathrm{H} \mathrm{NMR}\left(\mathrm{CDCl}_{3}\right) \delta 2.18(\mathrm{~s}, 3 \mathrm{H}, 7-\mathrm{CH} 3), 3.14(\mathrm{t}, \mathrm{J}$ $6.98 \mathrm{~Hz}, 2 \mathrm{H}, \mathrm{H}-\mathrm{C}^{\prime}$ '), $2.60(\mathrm{t}, J 6.74 \mathrm{~Hz}, 2 \mathrm{H}, \mathrm{H}-\mathrm{C} 7$ ') $1.44-1.48(\mathrm{~m}, J 6.98 \mathrm{~Hz}, J 6.74 \mathrm{~Hz}, J 6.23$ $\mathrm{Hz}, 4 \mathrm{H}, \mathrm{H}-\mathrm{C} 5$ ', H-C6'),3.73(s, 2H, NH$\left.{ }_{2}\right), 5.78$ (s, 1H, H-C5), 6.70-7.26(m, 9H, Ar, Ar'-N), $15.27(\mathrm{~s}, \quad 1 \mathrm{H}, \mathrm{NH}) ;{ }^{13} \mathrm{C}$ NMR(CDCl3) $\delta$ 19.91(C-7), 33.92(C-4'), 29.52(C-5'),28.45(C6'),35.41(C-7'),96.65 (C-3), 107.18 (C-5), 116.24 (C-5"), 118.49 (C-8"), 121.72 (C-4"), 127.27(C-6"), 127.73 (C-11"), 129.39 (C-9', C-13'), 129.61 (C-10', C-12'), 129.67(C7"), 140.10(C-9"), 163.58(C-6), 163.78(C-4), 178.35 (C-3'), 185.60 (C-2) ; EI MS m/z (\%) 376(25, $\left.\mathrm{M}^{+}\right)$; IR $\left(\mathrm{v}, \mathrm{cm}^{-1}\right) 3051,1682(\mathrm{C}=\mathrm{O}), 1596,1334 ; \mathrm{UV}\left(\lambda_{\max }\left(\varepsilon 10^{-1}\right) \mathrm{nm}\right) 228(1060)$, 319(764). Anal. Calcd. for $\mathrm{C}_{23} \mathrm{H}_{24} \mathrm{~N}_{2} \mathrm{O}_{3}$ : C, 73.38; H, 6.43;N, 7.44. Found: C, 73.42; H, 6.38;N, 7.50 .

Method for preparation 3-(1,3-dihydro-2H-benzimidazol-2-ylidene)-6-methyl-2H-pyran2,4(3H)-dione (18). A solution of 14a-c or $15(1 \mathrm{mmol})$ with o-PDA $(0.108 \mathrm{~g}, 10 \mathrm{mmol})$ in ethanol $(10 \mathrm{ml})$ was refluxed under MW irradiation at $100 \mathrm{~W}$ for $4 \mathrm{~min}$. After cooling and filtration, the resultant was crystallized from ethanol to give the compound $\mathbf{1 8}$ as light-brown powder; mp. $45{ }^{\circ} \mathrm{C} ;{ }^{1} \mathrm{H}$ NMR(DMSO) $\delta 2.15$ (s, 3H,7-CH3), 5.83 (s, 1H, H-C5), 7.32(d.d, J 8.59 
Hz, J 1.32 Hz, J 7.10 Hz, 2H, H-C6', H-C9'), 7.75(d.d, J 7.10 Hz, J 1.32 Hz, J 8.59 Hz, 2H, HC7', H-C8'), 13.15 (s, 2H, H-N4', H-N11'); ${ }^{13} \mathrm{C}$ NMR(DMSO) $\delta$ 19.33(C-7), 84.91(C-3), 107.63 (C-5), 113.11(C-5', C-8'), 123.77 (C-6', C-7'), 129.76(C-4', C-9'), 149.15(C-3'), 161.35(C-6), 163.56(C-2), 179.42 (C-4) ; EI MS m/z (\%) 242(18, M $\left.{ }^{+}\right)$; IR ( $\left.v, \mathrm{~cm}^{-1}\right) 1698(\mathrm{C}=\mathrm{O}), 1602,1422$; $\mathrm{UV}\left(\lambda_{\max }\left(\varepsilon 10^{-1}\right) \mathrm{nm}\right) 238(1256), 330(7854)$. Anal. Calcd. for $\mathrm{C}_{13} \mathrm{H}_{10} \mathrm{~N}_{2} \mathrm{O}_{3}$ : C, 64.46; H, 4.16; N, 11.56. Found: C, 64.52; H, 4.1;N, 11.60.

\section{General method for preparation 2-(2-arylethyl)-1H-benzimidazoles 19a-c and 2-(4- phenylbutyl)-1H-benzimidazole (20)}

A solution of 14a-c $(1 \mathrm{mmol})$ or $15(1 \mathrm{mmol})$ with o-PDA $(0.108 \mathrm{~g}, 1 \mathrm{mmol})$ in toluene $(10 \mathrm{ml})$ was refluxed under thermal heating or under MW irradiation at $200 \mathrm{~W}$ for $4 \mathrm{~min}$. After filtration at ebullition, TAL 9 was isolated and crystallized. After the cooling of the filtrate and filtration, the resultants were i crystallized from ethanol to yield the corresponding compounds 19a-c or 20. 2-[2-(4-Dichlorophenyl)ethyl]-1H-benzimidazole (19a). Brown powder; mp. $220{ }^{\circ} \mathrm{C} ;{ }^{1} \mathrm{H}$ NMR(DMSO) $\delta 2.90$ (t, J 7.41 Hz, 2H, H-C5'), 3.10(t, J 7.41 Hz, 2H, H-C4'), 7.02-7.43(m, 9H, Ar, Ar'), 9.85 (1H, H-N3); ${ }^{13} \mathrm{C}$ NMR (DMSO): $32.10\left(\mathrm{C}-4^{\prime}\right), 33.14$ (C-5'),113.60(C-6), 113.98(C-9), 122. 39(C-7), 124.40(C-8), 127.51(C-9'), 128.34(C-8', C-10'), 128.04(C-7',C-11'), 140.07(C-5), 140.31 (C-4), 140.96(C-6'), 160.11(C-2); EI MS m/z (\%) 222(55, M ${ }^{+}$); IR ( v, $\mathrm{cm}^{-}$ $\left.{ }^{1}\right)$ 3180, 3087, 1622, 1554, 1440; UV $\left(\lambda_{\max }\left(\varepsilon 10^{-1}\right) \mathrm{nm}\right) 228$ (1015), 315(964); Anal. Calcd. for $\mathrm{C}_{15} \mathrm{H}_{14} \mathrm{~N}_{2}$ : C, 81.05; H, 6.35. Found: C, 81.10; H, 6.32.

2-[2-(4-Dichlorophenyl)ethyl]-1H-benzimidazole (19b). Brown powder; mp. $165{ }^{\circ} \mathrm{C} ;{ }^{1} \mathrm{H}$ NMR(DMSO) $\delta 2.87(\mathrm{t}, J 7.52 \mathrm{~Hz}, 2 \mathrm{H}, \mathrm{H}-\mathrm{C} 5$ '), $3.05(\mathrm{t}, J$ 7.52 Hz, 2H, H-C4'), 7.08-7.44(m, 8H, Ar, Ar'), 9.86 (1H, H-N3); ${ }^{13} \mathrm{C}$ NMR (DMSO) 32.04(C-4'), 33.27 (C-5'), 113.58(C-6), 113.94(C9), 122. 42(C-7), 124.38(C-8), 126.51(C-9'), 128.90(C-8', C-10'), 129.33(C-7',C-11'), 140.10(C-5), 140.29 (C-4), 140.97(C-6'), 160.10(C-2); EI MS m/z (\%) 256(50, M ${ }^{+}$); IR ( v, cm $\left.{ }^{1}\right) 3178,3050,1624,1556,1446$; UV $\left(\lambda_{\max }\left(\varepsilon 10^{-1}\right) \mathrm{nm}\right) 228(1015), 315(964)$. Anal. Calcd. for $\mathrm{C}_{15} \mathrm{H}_{13} \mathrm{ClN}_{2}$ : C, 70.18; H, 5.10. Found: C, 70.24; H, 5.07.

2-[2-(3,4-Dichlorophenyl)ethyl]-1H-benzimidazole (19c). Brown powder; mp. $160{ }^{\circ} \mathrm{C} ;{ }^{1} \mathrm{H}$ NMR(DMSO) $\delta 2.89$ (t, J 7.47 Hz, 2H, H-C5'), 3.07(t, J 7.47 Hz, 2H, H-C4'), 7.12-7.43(m, 7H, Ar, Ar'), 9.83 (1H, H-N3); ${ }^{13} \mathrm{C}$ NMR (DMSO):, 32.06(C-4'), 33.51 (C-5'),113.57(C-6), 113.92(C-9), 122. 44(C-7), 124.29(C-8), 126.57(C-9'), 133.89(C-8'), 131.22(C-10'), 129.91(C7'),129.45(C-11'), 140.12(C-5), 140.27 (C-4), 140.25(C-6'), 160.08(C-2); EI MS m/z (\%) 290(30, $\left.\mathrm{M}^{+}\right)$; IR $\left(\mathrm{v}, \mathrm{cm}^{-1}\right) 3174,3056,1620,1556,1447$; UV $\left(\lambda_{\max }\left(\varepsilon 10^{-1}\right) \mathrm{nm}\right) 226(1025)$, 311(812). Anal. Calcd. for $\mathrm{C}_{15} \mathrm{H}_{12} \mathrm{Cl}_{2} \mathrm{~N}_{2}$ : C, 61.87; H, 4.15. Found: C, 61.84; H, 4.20.

2-(4-Phenylbutyl)-1H-benzimidazole (20). Brown powder; mp. $130{ }^{\circ} \mathrm{C} ;{ }^{1} \mathrm{H}$ NMR(DMSO) $\delta$ 1.42-1.50(m, J 6.98 Hz, J 7.19 Hz, J 7.27 Hz, 4H, H-C5', H-C6'), 2.80(t, J 7.27 Hz, 2H, H$\mathrm{C}^{\prime}$ ), 3.02(t, J $\left.6.98 \mathrm{~Hz}, 2 \mathrm{H}, \mathrm{H}-\mathrm{C} 4{ }^{\prime}\right)$ 7.10-7.49(m, 9H, H-Ar, Ar'), 9.87 (1H, H-N3); ${ }^{13} \mathrm{C}$ NMR(DMSO) $\delta$ 24.51(C-6'), 25.47 (C-5'), 30.41(C-4'), 35.63(C-7'), 113.21(C-6), 113.96(C-9), 122.57(C-7), 124.40(C-8), 126.42(C-11'), 129.30(C-10', C-12'), 129.73(C-9',C-13'), 140.12(C5), 140.14 (C-4), 141.24(C-8'), 160.02(C-2); EI MS m/z (\%) 250(45, $\left.\mathrm{M}^{+}\right)$; IR ( v, $\left.\mathrm{cm}^{-1}\right) 3180$, 
3097, 3048, 1628, 1552, 1441; UV ( $\left.\lambda_{\max }\left(\varepsilon 10^{-1}\right) \mathrm{nm}\right) 225$ (1148), 311(945). Anal. Calcd. for $\mathrm{C}_{17} \mathrm{H}_{18} \mathrm{~N}_{2}$ : C, 81.56; H, 7.25. Found: C, 81.61; H, 7.18.

4-Hydroxy-6-methyl-2-pyrone (triacetic acid lactone: TAL 9). White compound; mp. $187^{\circ} \mathrm{C}$; ${ }^{1} \mathrm{H}$ NMR(DMSO) $\delta 2.19$ (s, 3H, H-C7), 5.24(d, J $\left.2.23 \mathrm{~Hz}, 1 \mathrm{H}, \mathrm{H}-\mathrm{C} 3\right)$ 5.98(m, J 2.23 Hz, J 1.13 $\mathrm{Hz}, 1 \mathrm{H}, \mathrm{H}-\mathrm{C} 5), 11.5$ (s, 1H, H-O); ${ }^{13} \mathrm{C}$ NMR(DMSO) $\delta 19.37(\mathrm{C}-7), 88.15$ (C-5), 100.12(C-3), 163.18(C-4), 163.87(C-6), 170.47(C-2), EI MS m/z (\%) 126(81, $\left.\mathrm{M}^{+}\right)$; IR ( v, $\left.\mathrm{cm}^{-1}\right) 3100,2967$, $1763,1726,1590,1512,1368,1347$; UV $\left(\lambda_{\max }\left(\varepsilon 10^{-1}\right) \mathrm{nm}\right) 286$ (785). Anal. Calcd. for $\mathrm{C}_{6} \mathrm{H}_{6} \mathrm{O}_{3}$ : C, 57.14; H, 4.80. Found: C, 57.21; H, 4.76.

\section{Acknowledgements}

The authors are sincerely thankful to Pr. M. Hamdi, Professor at the Faculty of Chemistry, USTHB, Algeria, for help in the preparation of this work.

\section{References}

1. (a) Gantos, A.; De March, P.; Moreno-Manas, M.; Pla, A.; Sanchez-Ferrando, F.; Virgili, A. Bull, Chem. Soc. Jpn. 1987, 60, 4425. (b) Gellin, S.; Chantegrel B.; Nadi, A.I. J. Org. Chem. 1983, 48, 4078. (c) Djerrarie, B.; Essassi E.; Fifani, J. Bull. Soc. Chem. Fr. 1991, 128, 521. (d) Bendaas, A.; Hamdi M.; Sellier, N. J. Heter. Chem. 1999, 36, 1291. (e) Rachedi, Y.; Hamdi, M.; Sakellariou, R.; Spesiale, V. Synth. Comm. 1991, 21(10-11), 1189.

2. Ait Baziz, N.; Rachedi, Y.; Hamdi, M.; Silva, A. M.S.; Belegroune, F.; Thierry, R.; Sellier, N. J. Heter. Chem. 2004, 41, 587.

3. (a) Sucheta, K.; Prashant, A., Rama Rao, N. Indian J. Chem. 1995, 34B, 893. (b) Prakash, O.; Kumar, A.; Sadana, A.; Prakash, R.; Singh, S. P.; Claramunt, R. M.; Sanz, D.; Alkora, I.; Elguero, J. Tetrahedron 2005, 61, 6642.

4. Fodili, M.; Amari, M.; Kolli, B.; Robert, A.; Baudy-Floc'h, M.; Le Grel, P. Synthesis 1999,5, 811.

5. (a) Strakov, A. Y.; Choultcha, M.; Egle, A.; Mols Latv. A. PSR Zinat. Akad. Vestis, Kim.Ser. 1970, 615. (b) Qayyoom, M. A.; Hanumsnthu P.; Ratnazn, C. V. Indian J. Chem. 1982, 21 B, 883.

6. El abassi, M.; Assassi, E. M. Tetrahedron Lett. 1989, 30(50), 7069.

7. Djerrari, B.; Essassi, E.; J. Fifani, Garrigues, B. C. R. Chimie 2002, 5, 177.

8. (a) Bentley, R.; Zwitkowits, P. M. J. Am. Chem. Soc. 1967, 89, 676. (b) Bentley, R.; Zwitkowits, P. M. J. Am. Chem. Soc. 1967, 89, 681.

9. Collie, J. N. J. Chem. Soc. 1891, 59, 607.

10. Rachedi, Y.; Hamdi, M.; Spesiale, V. Synth. Comm. 1989, 19(20), 3437.

11. Aït-baziz, N.; Rachedi, Y.; Chemat, F.; Hamdi, M. Asian J. Chem. 2008, 4, 2610. 